\title{
GAINING A COMPETITIVE ADVANTAGE BY INTEGRATING ISLAMIC VALUES WITHIN COMPANY BEHAVIOR
}

\section{Syafaruddin Alwi}

Lecturer at the Faculty of Economic of the Indonesian Islamic University Yogyakarta

ملخص

فى الأونة الأخيرة وخاصة ما يحدث فى اندونيسيا عن تجارب نجد أن كثير ا من الاعمال

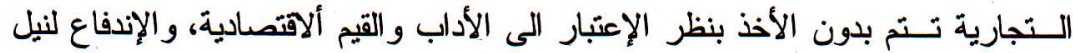

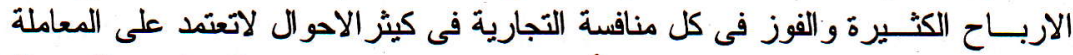

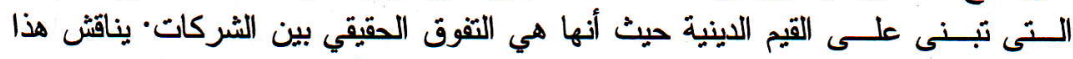

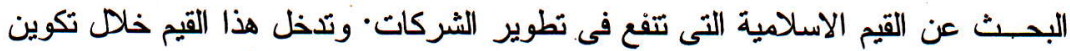

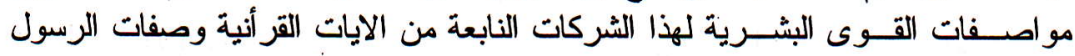

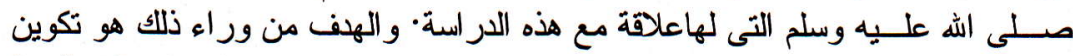

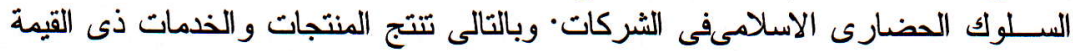
العلية و الصفة الشرعية لصالح المستهلكين.

\section{Abstrak}

Dewasa ini terutama pengalaman di Indonesia, banyak sekali terjadi praktekpraktek bisnis yang tidak mengindabkan norma-norma etika ekonomi yang normal. Hasrat meraih keuntungan dan menjadi pemenang dalam persaingan pasar, seringkali tidak menggunakan strategi-strategi bisnis yang bertumpu pada nilai-nilai religious yang sebenarny merupakan salah satu sumber keunggulan kompetitif bagi perusabaan. Tulisan ini membahas nilai-nilai dalam Islam yang bermanfaat bagi pengembangan kultur perusabaan. Nilai-nilai tersebut diintegrasikan melalui pembentukan karakter sumber daya manusia dalam perusabaan, yang digali dari sifat-sifat kepemimpinan Nabi Mubammad Saw dan ayat-ayat al-Qur'an yang relevan dengan topik sebagai dasar pembahasan. Impak yang diharapkan dari terbentuknya kultur yang Islami dalam 
perusahaan, akan menghasilkan produk-produk dan jasa-jasa yang valuable dan halal bagi pelanggan.

Keywords: competitive advantage, Islamic values, bussiness ethics

\section{A. Introduction}

Business Ethics, integrity and social accountability have become an important determinant of the quality of a company as a whole and companies are being held accountable for their societal role. Companies are able to bear responsibility in that respect by establishing their own general business principles or code of conduct. These should then clearly reflect the company's position toward business ethics.

One of the keys in the process of achieving customer satisfaction and customer values is customer relationship marketing. This means building strong relations with all stakeholders with the goal of delivering long-term value to the customer which leads to long-term customer satisfaction. It requires not only an accountable but even a pro-active relationship to develop a better product, thus improving customer value. High customer satisfaction is what one should strive for. This is the best approach to win over and maintain customers loyalty.

Many cases in Indonesia in the past decade showed that business practices employed unethical behavior. Some conventional banks practices, run by conglomeration group for example, were not running based on fairly economic norms. During the new order era, the monopoly and oligopoly practices caused by government policies became a fundamental economic process. Almost every company started with products without commitment to customer interest and values. For example, two years ago, the case of Ajinomoto's business practices, caused some Muslims in Indonesia to boycott the Company. They believed that Ajinomoto's product was not "balal" and was therefore forbidden by their religion. The business activities of LIPPO group are also troubled due to unfair management practices.

There are many practices manipulation of business transactions. It is, of course, not permitted by Islamic economic norms. Thus, each company needs a guideline and belief that the employee will follow when 
some time confronted with a situation in which a choice must be made. So that's why, in some cases, a company needs to reformulate its vision and mission under a new shared mind set (culture). With respect to the business circumstances, I propose that, using Islamic values is one of the best choices for managing organization, toward global market competition. For many reasons, these values must become the spirit of every company in market competition. But a company cannot practice its Islamic values until every manager and employee in the organization understand the spirit of these values. They must have a strong commitment to implement its values in day to day business activities.

In many cultures religion is a dominant aspect. As such, it can have a significant impact on how business is conducted by management, and attitudes about ethics. Islamic Banks for example, take equity in financing venture, sharing profit, as well as losses in the joint ventures. Gibson stated that Islam forbids excessive profit, which is considered exploitive. ${ }^{1}$ Islam preaches moderation and the sharing of wealth with others less fortunate. Muslims are expected to pray five times everyday. Companies and managers must be aware of this religious ritual and might consider making adjustments that would permit employee to stop working during prayer time.

From this point of view, I would like to answer the questions, why does a company need Islamic values as one of the best way toward competition. What kinds of values may exist in an organization and how do we integrate its values?

\section{B. Competitive Advantage Resources}

By definition, a competitive advantage is a special edge that allows an organization to deal with market and environmental forces better than its competitors. ${ }^{2}$ Theoretically, there are two kinds of competitive advantage resources i.e. through quality and operation management. The

${ }^{1}$ Ivancevic Gibson and Donelly, Organization (London: Time Mirror Higher Education Group Inc. Company, 1997), p. 62. 69.

${ }^{2}$ John R. Schermerhorn, Management (New York : John Wiley and Son Inc., 1996), p. 
key elements of the operation management approach to building competitive advantage are technology utilization, organization design and human resource utilization. Thus, one effective method for integrating Islamic values into company behavior is through building human resource utilization in the workplace. Through the human resource utilization approach, we may be able to change employee mindset from the old (notreligious oriented) to the new that is a religious mindset.

Shared mindset (identity and culture within business) in an organization is one of the important pillars of organization architecture. This pillar represent an organizational requirement for making business strategy more effective. The pillars of organization such as employee competence, governance, work process and leadership provide a framework that must be built for supporting strategy implementation. Organizational consultant David Nadler, with strategic logic uses an architecture metaphor to describe the system that exist within organizations including culture. ${ }^{3}$

From the above perspective, I believe that by integrating Islamic values into company behavior, manipulation in the business process can be avoided.

\section{Triangle Framework of Islamic Perspective}

Values are linked to attitudes in that a value serves as a away of organizing attitudes. The study of values is of course important to the study of managing organization. There is evidence that values are also fundamentally important for understanding effective managerial behavior for building employee commitment employee to fulfillment of stakeholder satisfaction. The values are important for managers to the field of company behavior because of their potential to influence workplace behavior.

Today, companies need a global as well as a local presence. They need to expand their markets not just penetrate them more deeply. They need to think strategically with their customers, not just sell them products

${ }^{3}$ Dave Ulrich, Human Resource Champions, The Next Agenda for Adding Value and Delivering Results (Boston, Massachusetts: HBS Press, 1997), p. 68. 
or services. The leaders in companies know intuitively that the success of their business depends upon how well people in the organization think together, create innovation together, and support and value each other. ${ }^{4}$ Cramer's statements, are very relevant to the Islamic perspective that tells us about cooperation. The holly Qur'an states: “And we raise some of them above others in ranks, so that some may command work from others" (Al-Zuhkruf: 32).

Islam also tells us about innovation: "Verily never will Allah change the condition of a people until they change what is in themselves" (Al Ra'du: 11).

Moreover, Islam also tells us about fairness, truth and trust in business practices. It is expected that Muslims people will fulfill their role at work as they fulfill their private obligation-following Islamic teachings. With respect to Indonesia business practices, al-Qur'an states: And, do not eat up your property among yourselves for vanities, nor use it as bait for the judges, with intent that ye may eat up urongfully and knowingly a little of other people's ( $\mathrm{Al}$ Baqarah: 188). To adopt this value, company strategy in conducting trade transaction for example must attempt to earn profit in fair ways. Thus, people in a company with religious personality is essential.

A set of Islamic values that is integrated within an organization is called organizational culture. This culture is often taken for granted but it helps people in organization or company understand which actions are considered acceptable and which unacceptable. This culture will influence company behavior. Culture became an issue in the 1980 s with attempts to unravel the secrets of Japanese business. Certain fundamental values in Japanese society, such as social solidarity, respect for elders, and strong work ethic, influence behavior in an organization. Generally, the Japanese corporate culture is supportive of senior based pay, job security, a qualitydriven systems of organization, importance of duty etc.

Ouchi in his theory $\mathrm{Z}$ developed some principles of company behavior as follow: a predominant concern for people, a guarantee of long-term employment, high trust and faith in the managers' ultimate

${ }^{4}$ Kathryn D. Cramer, When Faster Harder Smarter is Not Enough (New York: McGrawHill, 2000), p. 166. 
judgment and decision making based on shared values. ${ }^{5}$ Islam can also introduce a set of values in business such as innovation, respect for people as partners, concern for employee wages in proportion to effort, responsibility for the customer based on fairness, and trust. All of the values that are integrated within organization will lead to create employee behavior and employee behavior will lead to company behavior respectively. Company behavior based on its values will create a strong brand image for customer. It will lead to customer satisfaction and loyalty. This is the essence of this paper.

With respect to business strategy, it is known that Islamic culture can bolster the strategy of the company for gaining a competitive advantage in market competition. Integrating Islamic values in organization is the soft system approach to run a business. It is one of the best way to avoid a tendency for manipulation practices in business processes. Likewise strategy and culture can be interactive. Strategy and culture are interrelated and together are crucial for the success of company. Integrating these two factors in an organization needs a strong commitment from all people in the organization. This must be coming from the chief executive officers (in short CEO).

It is of course not easy to implement the above idea in a company where the old culture still exists. Change is not a painless process and it is often resisted by employees when they do not share the CEO' view. Therefore, the CEO must communicate to all people in the organization why the company needs its values.

For the future business, the value behind the product is therefore becoming a more important aspect for gaining a competitive advantage in market competition. Mission and vision will however remain empty words if the company is not united around a set of values- the corporate religion. Corporate religion is the set of values that unites the organization around a mission and vision. ${ }^{6}$

${ }^{5}$ Eugene McKenna and Nic Beech, The Essence of Human Resource Management (New York: Prentice Hall International,1995), p.52. 111.

Jesper Kunde, Corporate Religion (London: Financial Times Prentice Hall, 2000), p. 
As the globalization of business continues, companies must be run in a new way. Company vision can be analyzed into goals and values. This leads to outcomes of control and commitment and produces employee and manager behavior that fulfills stakeholder needs. In one study of 45 senior executives, the investigators found that, with one exception, each of the executives spoke with genuine interest and enthusiasm about shared values. Most said values were a very significant issue and that they spent a lot of time thinking about and discussing them. ${ }^{7}$

Image of the product is more and more associated with the image of the company. Customers are awareness has increased tremendously. Customers more and more hold companies accountable for their societal behavior. Customers make trade offs between products based on values and cost. In an era where differences in product quality area getting smaller, Companies should make use of the possibility to create a difference in the level and range of services they offer. Service has of course become a very important element in obtaining a competitive edge.

The competitive challenges that companies will face in the next decade will increase the importance of religious values for supporting fair global market competition. Successful companies both in the domestic or in the global market, have created organization with human resources and corporate culture that reflect the characteristic of stakeholders needs. Meeting stakeholder needs is one of the competitive challenges for companies. For a company which pursue only profit at the expense of everything else cannot survive in the $21^{\text {st }}$ century. ${ }^{8}$ They of course need to offer values as a business guideline.

The CEO of the company must be able to create trust, and a good image of the company especially for the customer. In the Islamic perspective, business transactions have to be carried out based on the balance between organizational goals and customer demand. Integrating values in organization that reflect ethical company behavior will create a strong commitment from employee to customer satisfaction and value.

${ }^{7}$ Gibson, Organization, p. 107.

${ }^{8} \mathrm{Kaku}$ Ryuzaburo, Win Jerry Yoram and Main Jeremy, Driving Change (New York: The Free Press, 1998), p. 46. 
Offering of its values through creating product or service quality and building customer relation will create good company image and customer loyalty. It is clear that values as the part of the soft systems in organization, will create employee's commitment to fulfillment of stakeholder needs i.e., customer need, shareholder needs, employee needs and society needs, etc.

The soft system as a guideline for companies is not a closed system. They take full advantage of the experiential learning process. Indeed, a commitment by an organization to stakeholder needs requires ethical behavior of employee and managers. The core values of organization in Islam can be developed based on principles of equality relationship among people (bablun min al-nass) and the relationship with Allab Almighty (bablun min Allab) that I call the triangle framework of Islam. Its values can then be adopted from the traits of Rasulullah Muhammad saw such as siddiq, amanah, tabligh and fatonah and from the holly Qur'an as a primary guideline for business practices.

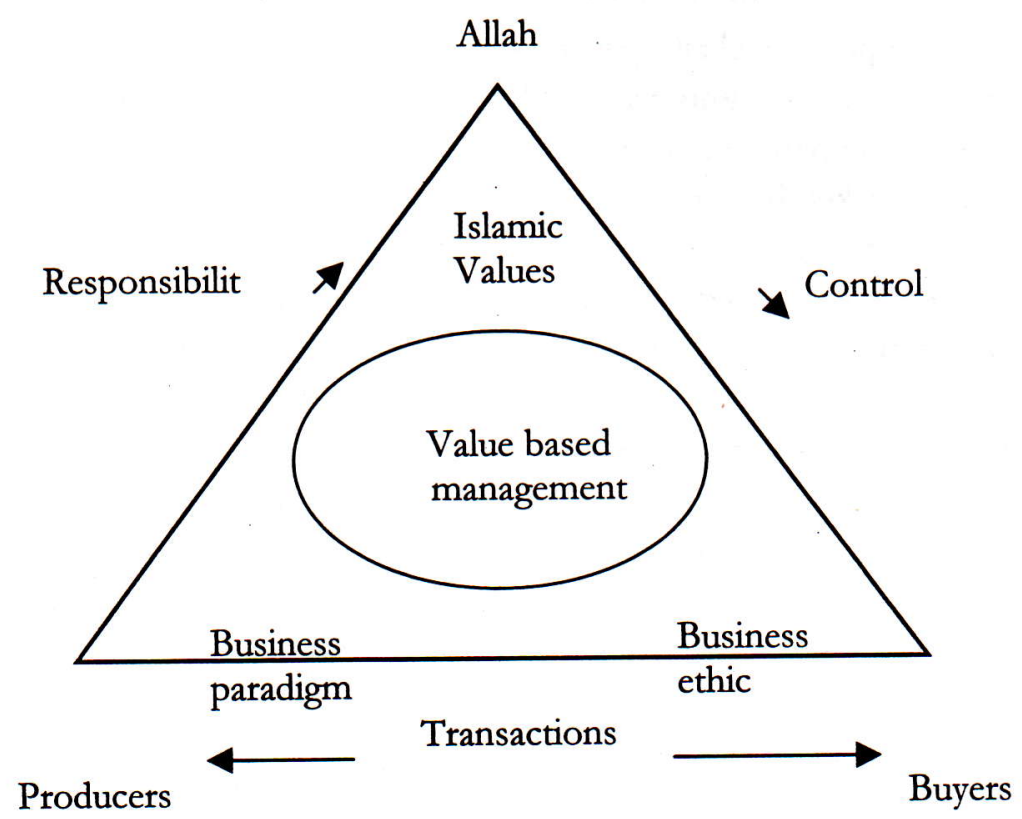

Figure 1: The Triangle Framework of Islamic

Perspective in Business Process 
This paper focuses therefore on the fundamental framework of Islamic perspective in business practices for gaining a competitive advantage. There are several ways to find it. One of them is through building company personality in the context of building human relations and "our relation" with Allah Almighty.

Employee behavior can be adopted from several traits of The Prophet Muhammad saw such as siddī (honesty), amanah (trustworthy), tabligh (communicative) and fatonab (intelligence). The impacts of its traits to both individual and company behavior, can be explained through table 1, as follows:

Table 1: The Religious Values and Its Impact on Employee and Company Behavior

\begin{tabular}{|l|l|l|}
\hline \multicolumn{1}{|c|}{$\begin{array}{c}\text { Religious } \\
\text { Values }\end{array}$} & \multicolumn{1}{|c|}{$\begin{array}{c}\text { Impact on Employee } \\
\text { Behavior }\end{array}$} & $\begin{array}{l}\text { Impact on Company } \\
\text { Behavior }\end{array}$ \\
\hline Siddiq & $\begin{array}{l}\text { Committed to clean business } \\
\text { process }\end{array}$ & $\begin{array}{l}\text { Building good } \\
\text { governance }\end{array}$ \\
\hline Amānah & $\begin{array}{l}\text { Committed to company } \\
\text { vision, mission and goals }\end{array}$ & $\begin{array}{l}\text { Committed to } \\
\text { stakeholder needs and } \\
\text { satisfaction }\end{array}$ \\
\hline Tabligh & $\begin{array}{l}\text { Sermon at religious meeting in } \\
\text { the work place in the context } \\
\text { of personal characteristic } \\
\text { building }\end{array}$ & $\begin{array}{l}\text { Concern in building } \\
\text { moral integrity in the } \\
\text { work place }\end{array}$ \\
\hline Fatonab & Creative mindset & $\begin{array}{l}\text { Product and service } \\
\text { innovation }\end{array}$ \\
\hline
\end{tabular}

Learning from table 1 for example, personal values based on The Prophet Muhammad'traits suh as siddiq will influence employees behaviors in an organization. They will be committed to clean business processes. It will then lead companies to run business based on good governance principles. Employees that work with amanah value have a strong commitment for reaching agreement with other employee to achieve the company vision, mission and goals. In the other side, a 
company should has a high commitment to customers satisfaction. High customer satisfaction is what one should strive for. It is the best approach to win and keep customer. Remember that customer loyalty is only possible with high satisfaction.

Gaining a competitive advantage by integrating Islamic values within company behavior, includes developing and keeping people as a key of business strategy. When businesses fail, it is rarely because of a bad product or poor economy. It is because people were allowed to fail. A culture was created policy by policy that did not recruit, train, reward, deploy, and energize people. 'The company leaders sometimes do not care about that.

Islamic values are applicable to code of ethics and teach us about trust in running a business. To achieve strong and successful position in the market competition, companies have to start thinking and acting along these lines.

The company vision may not have value based only on an economic sense. It may be in the religion sense too. Vision is where a company wants to be. A vision has intrinsic value. Therefore, the vision must contribute to creating motivation and commitment for all people in company. The Islamic perspective exposes that the business goals must be achieved through a fair way that everyone in the organization has a strong commitment to implement. For individual, Islamic perspective teaches us that each individual activities must be based on three principles:

Start your business activities after praying to God.

Đ Go every where that you are possible to earn some thing

$\square$ Remember God at any position and in activities

The first principle: Praying to God, as the way to surrender to God before working is important. It will create a high level of working spirit for employees to perform business goals. Employees will be ready to work hard based on religious values. Religious values will guide us to run a p. 23.

9Pacetta, Stop Whining and Start Winning (New York: Harper Collins Publisher, 2000), 
business. The second: go everywhere that you are possible to earn something means that everybody must attempt to create opportunity to earn rezqi such as income and profit from business activities. The third: always remember God will inspire employees in the working process for doing the best, both for the company and their customers. Remember God will create values as a guide for doing all of our activities. The last but not least, if we have carried out all steps of the activities, Allah will then bless us.

Those principles is obtained from the holly Qur'an, surat Al Jum'ah: 10: "And when the prayer is finished, then may ye disperse through the land, and seek of the bounty of Allab: and remember Allah frequently that ye may prosper"

By adopting these values, employees and business leader must attempt to reach organizational goals based on a religious ethic code. The management may adopt its values for being a company behavior that can be able to energize people in working. The company will motivate and educate their employees personality by building religious environment in the work place. The outcomes of this are, people can be the change agent, and these should then clearly reflect the company's position toward business success.

However, there is an urgent call for transferring the normative religious translating into operational concepts. We need to have a balance between subjective and objective approaches toward Islam. The subjective approach will strengthen the awareness on Islam as the basic ideological and normative guideline. While the objective approach will encourage us to conceptualize Islam into lively social praxis. ${ }^{10} \mathrm{I}$ agree with Sudibyo's statements but one thing that is important to note, both normative and or conceptualize can not be differentiated absolutely. It should be integrated.

Integrating values within a strategic framework can be drawn as figure 2, as shown on the next page. From this figure, I can explain that in achieving goals such as profit, growth, product quality etc, the organization needs infrastructures i.e., plan, policy, rule, procedure and reward for running business process.

${ }^{10}$ Sudibyo Markus, "Voluteerism And Human Survival, The Case of Da'wah Jamaah" in Islamic Millenium Volume II, January-March 2002, p. 63. 
Syafaruddin Alwi

Al-Qur'an introduces Islamic values that organizations must be managed based on business principles such as fairness, partnership or cooperation, and moral integrity. These principles create a strong commitment from employees for working harder, and smarter to meet stakeholder needs.

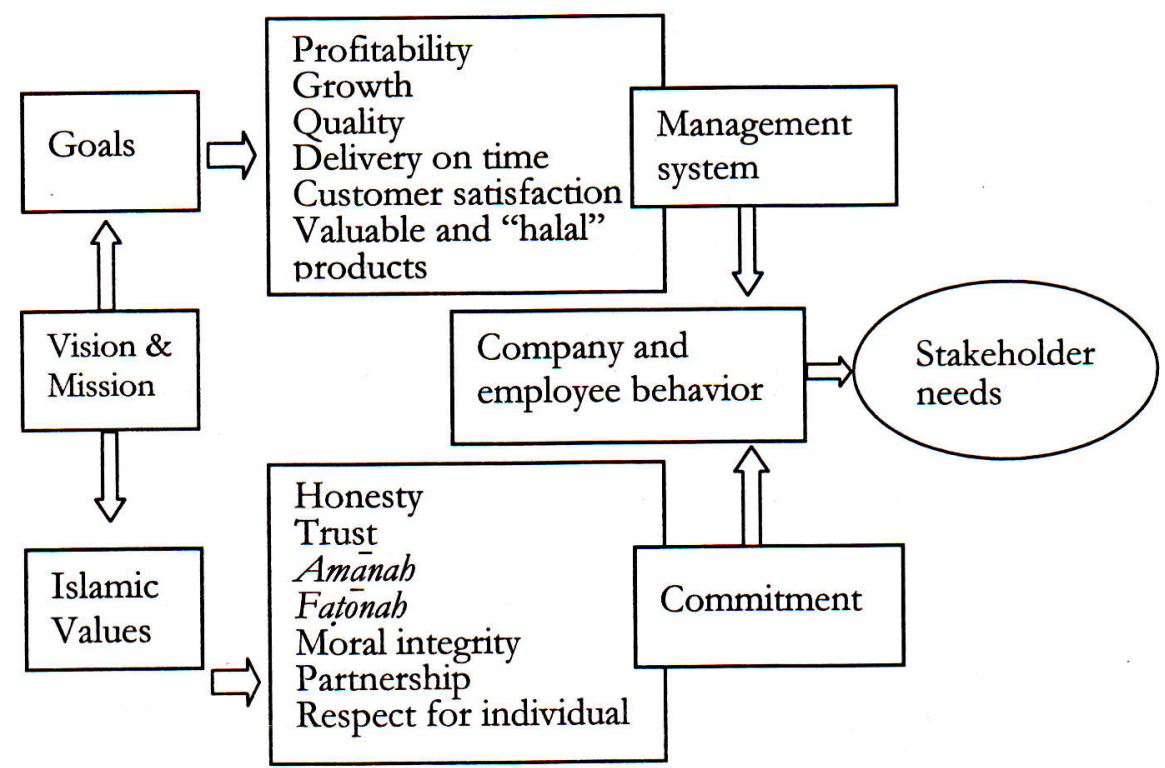

Figure 2: Integrating Values within A Strategic Framework

The problems now is how does the company management integrate its values within day to day business activities? Companies must be able to describe themselves internally because the quality and its values become crucial to the company's success or failure. According to Firman, The CEO of Xerox, several companies fail to run their business well because they are not able to translate company vision and its values into their business process. 


\section{People Centered Approach}

The answer of the question is basically through the people centered development approach. Through continuous training and training programs, effective communication and building silaturrabim between the $\mathrm{CEO}$ and other line managers and employees regularly is possible. Sermon at religious meeting in internal organization now is also very popular as the way to develop employee personality. More than it, employee involvement in reformulating the concept of changing culture from the old culture to the new culture is important. Islam in human resource development is clearly people centered. Individual according to al-Qur'an have been appointed by Allah Almighty as a khälifah. This means people in an organization that has conceptual skills, human skills and technical skills can be able to manage their business process effectively.

By creating a religious environment the business process can be operated based on fairness, trust etc. As al-Qur'an says: " $O$ you belief! Ward off yourselves and your families against the fire (of hell)" (Al-Tahrim:6). Many young managers that are successfull in managing their companies has been change their corporate strategy from focusing only on using a hard approach such as using technology, compensation, etc, to a soft approach oriented (focusing on cultural change). PT. Garuda Indonesia for example, by implementing information technology system, the management lead to change their business process, system and culture. They need a strong leader who can be able to act as the agent of change in the company. The change paradigm is fundamental in Islam.

Companies such as PT. Telkom Indonesia, have developed the role model in managing company that based on transparency, fairness and accountability. Its values are very relevant to the topic of this paper. Islamic value are universal. This means, all companies that want to be the winner in global market competition must consider Islamic values. It will create a cleared distinctive competence of employee. I belief that a strong leadership for the future must have a strong moral integrity. Employees are strategy.

Regarding the people centered development, Robert Waterman has provided an important insight on the connection between strategy and 
effectively managing people. ${ }^{11} \mathrm{He}$ recognized that organization, people, culture and capability are important sources of competitive advantage. Success come from successfully implementing strategy, not just from having one. This implementation capability derives, in large measure, from the organization's people, how they are treated. Thus, if we want to change an organizational culture, for the first step we must start by changing employees mind. After that, we may be possible to change their attitudes and their perception on Islamic values. Keep in our mind that not all of the employees can understand easily why Islamic values are essential for companies.

Corporate religion is about consensus, about uniting many minds in a common purpose. It is crucial for success that every employee has the same attitudes, the same perception and goes along the same shared path to create new organizational culture and values. A company religion ensure that all employees in a company share the same qualitative values. Values are at the heart of corporate culture. They are made up of the key beliefs and concept shared by an organization's employees. Successful companies are clear about these values and their managers publicly reinforce them. ${ }^{12}$

With respect to the above statements, the strategy of people centered development in the context of integrating its values within the company behavior must be focused on building employees commitment and creating a conducive human relationship in an organization. The management team must therefore works diligently to communicate to employees the intent of the changes. Employees commitment often come from a leader who share a clear vision that passionately communicate an intent. I am convinced if employees understand why some thing is being done, they will more readily accept what is expected.

${ }^{11} \mathrm{Jeffrey}$ Pfeffer, Human Equation: Building Profit by Putting People First, (Boston Massachusetts: Harvard Business School Press, 1998), p. 17.

${ }^{12}$ Alan Price, Human Resource Management in A Business Context, (London: Thomson, 1997), p. 140. 


\section{BIBLIOGRAPHY}

The Holy Qur'an: English Translation of the Meaning and Commentary, Madinah: King Fahd Holy Qur'an Printing Complex, $1410 \mathrm{H}$.

Bennis Warren, Managing People is Like Herding, London: Biddles Ltd, 1999.

Cramer Kathryn D., When Faster Harder Smarter is Not Enough, New York: McGraw-Hill, 2000.

Covey Stephen R., The 7 Habits of Highly Effective People, New York: Simon and Schuster, 1989.

Gibson, Ivancevic and Donelly, Organization, London: Time Mirror Higher Education Group Inc.Company, 1997.

Jackson David, Becoming Dynamic: Creating and Sustaining the Dynamic Organisation, New York: MacMillan Press Ltd, 2000.

Kunde Jesper, Corporate Religion, London: Financial Times Prentice Hall, 2000.

McKenna Eugene and Nic Beech, The Essence of Human Resource Management, New York: Prentice Hall International, 1995.

Markus Sudibyo, "Voluteerism And Human Survival, The Case of Da'wah Jamaah" in Islamic Millenium Volume II, January-March 2002.

Price Alan, Human Resource Management in A Business Context, London: Thomson Business Press, 1997.

Pfeffer Jeffrey, Human Equation: Building Profit by Putting People First, Boston Massachusetts: Harvard Business School Press, 1998.

Pacetta, Stop Whining and Start Winning, New York: Harper Collins Publisher, 2000.

Ryuzaburo Kaku, in Win Jerry Yoram and Main Jeremy, Driving Change,

New York: The Free Press, 1998.

Schermerhorn, John R., Management, New York: John Wiley and Son Inc., 1996.

Ulrich Dave, Human Resource Champions, The Next Agenda for Adding Value and Delivering Results, Boston, Massachusetts: HBS Press, 1997.

Winter Graham, High Performance Leadership, New York: John Wiley \& Sons Pte Ltd., 2003.

Zwell Michael, Creating $A$ Culture Of Competence, Toronto: John Wiley \& Sons, INC., 2000. 